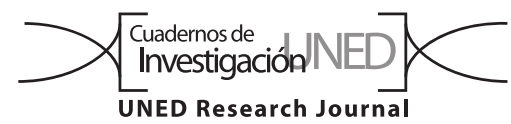

\title{
Distribution and abundance of mosquito larvae in Ohafia, Abia State, Nigeria
}

\author{
Onyekachi Egwu' ${ }^{1}$ Carmelita C. Ohaeri', Ebube C. Amaechi ${ }^{1,2}$ \& Collins N. Ehisianya ${ }^{1}$ \\ 1. Department of Zoology and Environmental Biology, Michael Okpara University Agriculture, Umudike, PMB 7267, Umuahia, Abia State, \\ Nigeria; ebubeamechi@yahoo.com \\ 2. Department of Zoology, University of Ilorin, Ilorin.
}

Received 15-XII-2017 • Corrected 27-III-2018 • Accepted 04-IV-2018

\begin{abstract}
Quite a number of diseases are transmitted by mosquitoes. The abundance and distribution of mosquito vectors are related to the characteristics of larval habitats. A survey of the distribution and abundance of mosquito larvae was carried out at Nkporo and Abiriba Communities of Ohafia, Abia State, Nigeria. It was carried out during the dry and wet seasons from November 2014 to June 2015. The mosquito larvae were collected using dipper and pipette method from five mosquito habitats namely ground pools (58), household containers (213), domestic run-offs (49), gutters (55) and tree holes/leaf axils (43). A total of 2641 mosquito larvae belonging to three genera and five species were collected. These were; Culex quinquesfaciatus (40\%),Aedes aegypti (22\%), Aedes albopictus (17\%), Anopheles gambiae (14\%), and Anopheles funestus (2\%), Household containers had the highest number of larvae $(60 \%)$, while tree holes/leaf axils had the least (6\%). From Nkporo, 53\% of the larvae were collected while $47 \%$ was from Abiriba community. Anopheles funestus was recorded only in Nkporo community. However, the abundance of mosquito larvae sampled from the different habitats in the two communities were significantly different $\left(X^{2}=166,692, d f=\right.$ $16, P<0,05)$ from each other. There were also significant differences in the seasonal distribution of mosquito larvae in both dry $\left(X^{2}=56,865\right.$, df $=12, P<0,05)$ and wet $\left(X^{2}=22,241, d f=12, P<0,05\right)$ seasons in Nkporo community and dry $\left(X^{2}=31,776, d f=12, P<0,05\right)$ season in Abiriba community. These findings are useful in knowledge expansion on the vector ecology with particular interest on the type of habitat preference, this will be helpful in larval control programs.
\end{abstract}

Keywords: Mosquito, Larval habitats, Seasonal distribution, Abundance, Ohafia, Nigeria.
RESUMEN: Distribución y abundancia de larvas de mosquitos en Ohafia, estado de Abia, Nigeria. Una gran cantidad de enfermedades son transmitidas por mosquitos. La abundancia y distribución de mosquitos vectores están relacionadas con las características de los hábitats larvarios. Se realizó un estudio de la distribución y abundancia de larvas de mosquitos en las comunidades de Nkporo y Abiriba, Ohafia, estado de Abia, Nigeria. Se llevó a cabo durante las estaciones seca y húmeda de noviembre de 2014 a junio de 2015. Las larvas de mosquitos se recolectaron utilizando el método de cucharón y pipeta de cinco hábitats de mosquitos, a saber: piscinas molidas (58), contenedores domésticos (213), escorrentías domésticas (49), canales (55) y agujeros de árboles / axilas de hojas (43). Se recolectó un total de 2641 larvas de mosquito pertenecientes a tres géneros y cinco especies. Éstas eran; Culex quinquesfaciatus (40\%), Aedes aegypti (22\%), Aedes albopictus (17\%), Anopheles gambiae (14\%) y Anopheles funestus (2\%). Los contenedores domésticos presentaron el mayor número de larvas (60\%), mientras que los agujeros de los árboles / axilas de las hojas fueron los que menos (6\%). De Nkporo, el 53\% de las larvas fueron recolectadas, mientras que el $47 \%$ fue de la comunidad de Abiriba. Anopheles funestus solo se registró en la comunidad de Nkporo. Sin embargo, la abundancia de larvas de mosquitos muestreados de los diferentes hábitats en las dos comunidades fue significativamente diferente $\left(X^{2}=166,692\right.$, $\mathrm{df}=16, \mathrm{P}<0,05)$ entre sí. También hubo diferencias significativas en la distribución estacional de las larvas de mosquitos en las estaciones tanto secas $\left(X^{2}=56,865, d f=12, P<0,05\right)$ como húmedas $\left(X^{2}=22,241\right.$, $\mathrm{df}=12, \mathrm{P}<0,05)$ en la comunidad de Nkporo y secas $\left(\mathrm{X}^{2}=31,776, \mathrm{df}=\right.$ $12, \mathrm{P}<0,05)$ en la comunidad de Abiriba. Estos hallazgos son útiles en la expansión del conocimiento sobre la ecología vectorial con especial interés en el tipo de preferencia de hábitat, esto será útil en los programas de control de larvas.

Palabras clave: Mosquito, hábitats larvales, distribución estacional, abundancia, Ohafia, Nigeria.
Mosquito-borne diseases pose a major threat to both human populations and diversity of indigenous fauna throughout the world where they transmit diseases to more than 700 million people annually (Adeleke,
Mafiana, Idowu, Sam-Wobo \& Idowu, 2010). Species tend to breed in both natural habitats and artificial containers such as ground pools, gutters, domestic run-offs, tree holes, septic tanks (Mafiana et al., 1989; Okogun, 
Nwoke, Okere, Anosike \& Esekhegbe, 2003; Aigbodion \& Anyiwe, 2005). Environmental and climatic factors directly influence the distribution of mosquito larvae (Mafiana, Anaeme \& Olatunde, 1998).

Studies to determine the distribution and abundance of mosquito larvae in various habitats have been carried out in various parts of Nigeria (Adeleke, Mafiana, Idowu, Adekunle \& Sam-Wobo, 2008; Olayemi, Ukubuiwe \& Oyibo-Usman, 2014; Akpan \& Nwabueze, 2015). Species encountered in the various studies include Anopheles gambiae, Aedes aegypti, Culex quinquefasciatus, Mansonia africana, etc. These studies will help to ascertain the present state of the different mosquito species in each locality as this is necessary in mosquito control. For any vector control measures to be successful, knowledge of the breeding ecology of mosquitoes including, the types and preferences for larval habitats, spatial and temporal distribution of breeding sites, as well as, the physical, biological and chemical characteristics of the habitats are required (Olayemi, Omalu, Famotele, Shegna \& Idris, 2010; Egbuche, Ezihe, Aribodor \& Ukonze, 2016; Goselle et al., 2017). The continued transmission of mosquito borne diseases is associated with climatic factors and the vast larval habitats that exist in a particular environment that necessitates breeding of the vectors (Oluwasogo et al., 2016). Studies to identify mosquito larval habitats have been carried out in several parts of Nigeria including Abeokuta (Mafiana et al., 1998; Adeleke et al., 2008), Ekpoma (Okogun et al., 2003), Uyo (Usip \& Edem, 2003) and Awka (Mbanugo \& Okpalononuju, 2003). Therefore, this study was to determine seasonal distribution and abundance of mosquito larvae at Nkporo and Abiriba communities of Ohafia, Abia State, south eastern Nigeria.

\section{MATERIALS AND METHODS}

Study Area: This study was carried out in two communities namely Nkporo and Abiriba at Ohafia Local Government Area (Latitude 05037"N - 5 $617^{\prime \prime} \mathrm{N}$ and longitude $7^{\circ} 50^{\prime \prime} \mathrm{E}$ and $7^{\circ} 833^{\prime \prime} \mathrm{E}$ ) of Abia State, southeastern Nigeria. The study area is within the tropical rainforest zone of Nigeria with two clearly distinguishable annual seasons - wet and dry seasons. The annual rainfall ranges from 1750 to $2000 \mathrm{~mm}$ and a mean annual temperature range of $26^{\circ} \mathrm{C}$ to $28^{\circ} \mathrm{C}$. The entire Local Government Area has a population estimation of 350000 inhabitants (National population commission, 2006). Two communities were selected purposely selected to represent rural (Nkporo) and Peri-urban (Abiriba) settlements in the local Government Area. The communities were selected due to their different population size which affects human activities.

Methodology: Investigations were carried arbitrarily in selected streets, roads, private and public residences and open places to determine seasonal distribution and abundance of mosquito larvae. Larval sampling was done monthly between 07.00 and 11.00 hours for eight months (from November 2014 to June 2015) representing (four months each of wet and four dry seasons). The larvae in the ground pools, containers, gutters and domestic run-offs were collected with the aid of plastic dippers while pipette was used for the collection of larvae from tree holes. Dippers could not be used in containers. Therefore, the water in them were emptied into the bowls and larvae collected according to (Service, 1993). The larvae collected were poured through a fine sieve into a white bowl to concentrate them. All collected larvae were transferred into labelled specimen bottles and transported to laboratory for rearing and identification.

Habitat characteristics recorded included the presence of vegetation, the intensity or duration of sunlight and the depth of aquatic microhabitat, submerged, emergent and terrestrial vegetation. Algal cover and debris were estimated as percentage of the habitats using a square grid.

In the laboratory, larvae were kept in bowls covered with a fine nylon mesh, to prevent emerging adults from flying away. They were subsequently transferred into rearing cage.

The cages were stood in tomatoes tins containing water to deny ants and other predators access to the larvae. The larvae were fed with a mixture of yeast and biscuits. The set up was monitored daily until the emergence of adults.

Data were analysed using Chi-Square SPSS version 20.0

\section{RESULTS}

Mosquito breeding habitats and mosquito abundance at Ohafia L.G.A: The mosquito larvae habitats identified from the study area were ground pools $14 \%$, containers $51 \%$, domestic run-offs $12 \%$, gutters $13 \%$ and tree holes $10 \%$. Containers had the highest breeding habitats followed by ground pools while the least was tree hole. Similarly containers housed the highest number of mosquito larvae, followed by ground pools then domestic runoff, while tree holes contained the least number (Table 1). $\left(X^{2}=1,036 ; d f=4, p>0,05\right)$. 
TABLE 1

Percentage of mosquito breeding habitat type's abundance of larvae in Nkporo and Abiriba communities in Ohafia, Abia State.

\begin{tabular}{|c|c|c|c|c|c|c|}
\hline Location & Ground Pools & Containers & Domestic Run-offs & Gutter & Tree holes & Total \\
\hline Nkporo & 13,7 & 49,3 & 11,5 & 15,42 & 10,1 & 54,3 \\
\hline \multirow[t]{2}{*}{ Abiriba } & 14,1 & 52,9 & 12,0 & 10,47 & 10,5 & 45,7 \\
\hline & 13,9 & 51,0 & 11,7 & 13,2 & 10,3 & \\
\hline
\end{tabular}

Distribution of mosquito larval species collected in the study area: The abundance and distribution of species of mosquitoes in the study area is shown in Table 2. Culex quinquefasciatus recorded the highest population (40\%), followed by Ae. aegypti (27\%), then Ae. albopictus (17\%), while the number of An. gambiae collected was (14\%). The least larval species collected was An. funestus (2\%) and it was found to breed only at Nkporo community.

The percentage of An. gambiae collected from Nkporo $(60 \%)$ were significantly higher compare with those collected from Abiriba (40\%) respectively, whereas $100 \%$ of the An. funestus were caught in Nkporo community. In contrary, a higher population of Ae aegypti were collected in Abiriba community than in Nkporo community i.e. $52 \%$ and $48 \%$ respectively. Similarly, a higher population of Ae. albopictus were collected in Abiriba (53\%) community, while $48 \%$ were in Nkporo community. Higher population of Culex (55\%) were caught in Nkporo community while $45 \%$ were caught in Abiriba community. Statistical analysis shows that there was significant different $\left(X^{2}=81,335, d f=4, p<0,05\right)$ in the distribution of mosquito larval species caught in the study area.

TABLE 2

Distribution of mosquito larval species collected in the study area.

\begin{tabular}{lcc}
\multicolumn{1}{c}{ Mosquito Larval Species } & Nkporo (\%) & Abiriba (\%) \\
Culex quinquefasciatus & 55 & 45 \\
Aedes aegypti & 48 & 52 \\
Aedes albopictus & 48 & 53 \\
Anopheles gambiae & 60 & 40 \\
Anopheles funestus & 100 & 0 \\
Total & 54 & 47 \\
\hline
\end{tabular}

Seasonal/monthly distribution of mosquito larval species in the study area: In Nkporo community, the highest collection (56\%) was made in November during the dry season, followed by (30\%) in December. Then the month of January (10\%) and the least collections were made in the month of February (4\%). In the month of November, C. quinquefasciatus were the highest larvae caught, (40\%). While An. funestus were the least larvae collected. Same trend was seen in all the other months of dry season in Nkporo community. However, statistical analysis shows that there was statistical difference $\left(X^{2}=56,865, d f=12, p<0,05\right)$ in the monthly distribution of mosquito larval species during dry season in Nkporo community.

During the rainy season in Nkporo community, highest collection were made in the month of June $(53 \%)$, followed by the month of May (26\%), then the month of April (17\%). The least collections were made in the month of March (5\%). Ae. Aegypti had the highest collection in the month of March (26\%), while An. funestus were the least $(0,00 \%)$. In the month of April, the larvae collected in highest number were $C$. quinquefasciatus (42\%), while An. funestus were the least (4\%). This trend also was observed in other months of the rainy season in Nkporo community. The month of May recorded (40\%) for C. quinquefasciatus. While An. funestus (4\%). However in the month of June, $C$. quinquefasciatus also recorded the highest collection of (40\%) while An. funestus was the least (4\%). Statistical analysis shows that there was significant difference $\left(X^{2}=22,241, d f=12, p<0,05\right)$ in the monthly distribution of mosquito larval species during rainy season in Nkporo community.

During dry season in Abiriba community, the month of November contained highest number of collections (51\%) followed by December (30\%), then January (17\%) and the month of February had the least number (3\%). An. funestus were not caught in any of the months of the dry season. While $C$. quinquefasciatus were the highest mosquito larval species caught in all the month of the dry season in Abiriba community. Statistical analysis shows that there was significant difference $\left(X^{2}=31,776\right.$, $\mathrm{df}=12, \mathrm{p}<0,05)$ in the monthly distribution of mosquito larval species during dry season in Abiriba community.

During rainy season in Abiriba community the month of November was when the highest collections were made (54\%) and the least collections were made in the month of March (4\%). Ae. aegypti had the collections of 
TABLE 3

Seasonal/monthly distribution of mosquito larval species in the study area (\%)

\begin{tabular}{|c|c|c|c|c|c|c|c|c|}
\hline Location & Season & Month & $\begin{array}{l}\text { Anopheles } \\
\text { gambiae }\end{array}$ & $\begin{array}{l}\text { Anopheles } \\
\text { funestus }\end{array}$ & $\begin{array}{l}\text { Aedes } \\
\text { aegypti }\end{array}$ & $\begin{array}{l}\text { Aedes } \\
\text { albopictus }\end{array}$ & $\begin{array}{c}\text { Culex } \\
\text { quinquefasciatus }\end{array}$ & Species Total \\
\hline \multirow[t]{8}{*}{ NKPORO } & \multirow[t]{4}{*}{ DRY } & Nov & 15,4 & 7,0 & 26,3 & 11,0 & 40,4 & 55,5 \\
\hline & & Dec & 13,7 & 6,5 & 13,7 & 19,4 & 46,8 & 30,2 \\
\hline & & Jan & 19,1 & 0,0 & 4,8 & 14,3 & 61,9 & 10,2 \\
\hline & & Feb & 23,5 & 0,0 & 5,9 & 29,4 & 41,2 & 4,1 \\
\hline & \multirow[t]{4}{*}{ WET } & Mar & 32,0 & 0,0 & 26,0 & 18,0 & 24,0 & 5,0 \\
\hline & & April & 18,1 & 3,6 & 27,1 & 9,6 & 41,6 & 16,6 \\
\hline & & May & 17,0 & 3,5 & 23,6 & 16,2 & 39,8 & 25,9 \\
\hline & & June & 13,5 & 4,0 & 27,0 & 15,4 & 40,1 & 52,5 \\
\hline \multirow[t]{8}{*}{ ABIRIBA } & \multirow[t]{4}{*}{ DRY } & Nov & 10,7 & 0,00 & 28,4 & 18,1 & 42,8 & 50,7 \\
\hline & & Dec & 12,8 & 0,00 & 30,4 & 16,0 & 40,8 & 29,5 \\
\hline & & Jan & 8,6 & 0,00 & 27,1 & 11,4 & 52,9 & 16,5 \\
\hline & & Feb & 7,14 & 0,00 & 57,1 & 7,1 & 28,6 & 3,3 \\
\hline & \multirow[t]{4}{*}{ WET } & Mar & 12,9 & 0,0 & 38,7 & 12,9 & 35,5 & 100,0 \\
\hline & & April & 7,7 & 0,0 & 31,9 & 17,6 & 42,9 & 3,9 \\
\hline & & May & 11,55 & 0,0 & 31,9 & 16,3 & 40,2 & 11,30 \\
\hline & & June & 14,81 & 0,0 & 29,9 & 23,4 & 31,9 & 31,2 \\
\hline
\end{tabular}

the collection made in the month of March (39\%), while An. funestus was the least (0.00). Infact, An. funestus was not found during rainy season in Abiriba community. Apart from the month of March, all other months, April $(43 \%)$, May (40\%) and June (32\%), C. quinquefasciatus recorded the highest number of collections. Statistical analysis shows that there was no significant difference $\left(X^{2}=8,830, d f=12, p>0,05\right)$ in the monthly distribution of mosquito larval species during rainy season in Abiriba community. (Table 3)

\section{DISCUSSION}

This study revealed that five species from three genera of mosquito larvae were present in the study area. Two Anopheles species larvae were collected (An. gambiae and An. funestus), two Aedes species (Ae. aegypti and Ae. albopictus) and one Culex species ( $C X$. quinquefasciatus). This is probably due to the presence of suitable breeding habitats such as domestic water containers, run-offs, gutters and other breeding places created by man. This results are similar to reports by different researchers from different parts of Nigeria (Oguoma \& Ikpeze, 2008; Umaru, Akogun \& Owuama, 2006; Onyido, Ezike, Ozumba, Nwankwo \& Nwankwo, 2009). Of the five breeding habitats sampled during the study in the two communities, it was observed that containers had the highest number of mosquito larvae $(60,02 \%)$ while the tree holes recorded the least number of mosquito larvae $(6,40 \%)$. This agrees with the work done by Awolola, Oyewole, Koekemoer and Coetzee (2005), Okogun (2005), Anosike et al. (2007) and Adeleke et al. (2010), who noticed that domestic containers were the preferred breeding habitats of mosquitoes. Okogun et al. (2005) also noted that the greater number of larvae observed in containers was due to the absence of or reduced larvae predation by mosquito natural enemies in such habitat. These were also seen in the result of this study. According to Mafiana et al. (1998), tree holes can only retain water for short period of time and dry up at the time of no rain. This may be the reason to explain the low contribution of tree holes to the breeding of mosquito in the study.

Different mosquito species use different habitats for breeding as well as water quality (Onyido et al., 2009). This observation agreed with this study. Some species are restricted to a single type of breeding habitat and water quality. Others possess a larger adaptability, but their presence in a given type of breeding site was due to oviposition habits of the female mosquito which is the main determining factor of the presence of larvae in different types of larval habitats. Worthy to note in this study, was the high prevalence of $C x$. quinquefasciatus in all the habitats. This is not a surprise because of its preference for polluted water (Mafiana et al., 1998). It was also observed in the current study that $C x$. quinquefasciatus was not only caught in large quantities from dirty domestic 
runoffs and gutters. Anopheles gambiae was another species of mosquito that was found in all the habitats in high quantities. The high prevalence of An. gambiae can be explained by the fact that the female species of An. gambiae preferentially select these habitats for oviposition and this is also in agreement with the works of Bentley and Day (1989). Furthermore, it was observed that An. gambiae had high occurrence in containers, domestic run offs and gutters shows that An. gambiae can utilize other habitats apart from ground pools which was originally known (Igbinosa, 1989). Although it was observed that the Anopheles species lacked the ability to breed in containers but, evidence from this work showed that Anopheles species can utilize containers as well as other habitats as breeding sites. This result corroborates the work of Opoku, Ansa-Asare and Amoako (2005) which reported that anopheles species also occur in a wide range of habitats, but with relatively low nutrient status and high oxygen level, and which also in agreement with the findings of Aigbodion and Odiachi (2003), who documented large numbers of An. gambiae in containers, domestic run-offs and gutters. Ae. aegypti was also found to be high in this study, mostly their remarkably high prevalence in tree holes. The indiscriminate breeding habit displayed by Ae. aegypti has been reported by Adeleke et al. (2008). Also, according to Sattler et al. (2005) the species preference of breeding site was not only for the site in question but also for the water quality: depth, light and vegetation which served as sources of food and shelter appropriate for their survival and development. According to findings from this study, it was observed that all the mosquito genera preferred shallow water to deep type. It was observed that light does not have much effect on the abundance of Culex and Aedes while anopheles preferred mostly sunlight and semi-shaded water. In addition, all the mosquito genera found in the study area existed in the habitat without vegetation and in the presence of algae. While it was observed that they lack preference for water with floating plants.

Seasonal variations were also observed in the abundance and distribution of mosquito larvae in the study area. Collections made during the rainy season were about two-third of all the mosquito larvae collected in both rainy and dry season. These findings agreed with that of Bunza, Suleiman, Yusuf and Bala (2010). From this study, the month of June which had the highest amount of rainfall recorded the highest number of larvae encountered during the study. High rate in abundance of mosquito larvae in the month of June and other months of wet seasons showed that rainfall is a key factor in determining mosquito breeding rate. The study in Kenya also showed that the rainy season presents favourable environmental conditions that enhance mosquito breeding and survival through the proliferation of larval habitats and improved humidity respectively (Minakawa, Pamela \& Yan, 2002). Also, similar findings by Jaensen, Niklasson and Henriksson (1986) on influence of weather and hydrological conditions on mosquito abundance have been demonstrated. C. quinquefasciatus was the most encountered species in all of the eight months of this study. This might be attributed to the presence of open drains, cracked and open septic tanks,flooded drains and natural containers that were mostly polluted with organic matter. while Ae. aegypti was another species that was encountered in a high number during both dry and rainy seasons.

This is an indication that the climatic and environmental conditions of Abiriba and Nkporo communities are conducive to support the survival and development of the mosquito vector. Surprisingly, An. funestus was only caught in some months of dry season (November and December) and some months of rainy season (April, May and June) in Nkporo community, but was not found at all in all the months of both dry and rainy seasons in Abiriba community. Anopheles funestus breeds normally in fairly clean, sunlit, small collections of standing water. This was in existence in some areas of Nkporo community and was probably the reason behind the presence of A. funestus in that area.

The outcome of this study indicates that there was a high vector breeding sites and therefore, vector control measures should be properly applied in the area. This requires proper environmental planning and surveillance. This is important to avoid the risk of outbreak of mosquito-borne diseases in the area.

This study has provided vital information to the distribution and abundance of mosquito larvae within Ohafia Local Government Area. A combination of factors of abundant rainfall, tropical temperatures and high relative humidity, breakdown of public pipe borne water systems that cause people to store up water in containers, increase in human development efforts, indiscriminate disposal of tins and cans used for food, all these and many more accounted for mosquito breeding both in dry and wet period of the study. Eliminating such mosquito breeding areas can be an extremely effective and permanent way to reduce mosquito population without resorting to insecticides.

\section{ACKNOWLEDGEMENTS}

We are grateful to Ohafia Local Government for the support we received in the course of this work. We are 
also grateful to community leaders and members of Nkporo and Abiriba communities for their cooperation during sample collection.

\section{REFERENCES}

Adebote, D. A., Oniye, S. J., \& Mohammed, Y. A. (2008). Studies on Mosquitoes Breeding in Rock Pools in Inselbergs around Zaria, Northern Nigeria. Journal of Vector Borne Disease, 45, 21-28.

Adeleke, M. A., Mafiana, C. F., Idowu, A. B., Adekunle, M. F., \& Sam-Wobo, S. O. (2008). Mosquito Larval Habitats and Public health Implication in Abeokuta, Ogun State, Nigeria. Tanzanian Journal of Health Research, 2, 103107. doi:10.4314/thrb.v10i2.14348

Adeleke, M. A., Mafiana, C. F., Idowu, A. B., Sam-Wobo, S. O., \& Idowu, O. A. (2010). Population Dynamics of Indoor sampled Mosquitoes and their Implication in Disease Transmission in Abeokuta, South western Nigeria. Journal of Vector Borne Disease, 47, 33-38.

Aigbodion, F. I., \& Odiachi, F. C. (2003). Breeding Sites Preferences of Anopheline Mosquitoes in Benin City, Nigeria. Nigerian Journal of Entomology, 20, 1-7.

Aigbodion, F. I., \& Anyiwe, M. A. (2005). Mosquitoes and the environment: Some economic costs of malaria in Nigeria. Nigerian Journal of Entomology, 22, 93-107.

Akpan, I.M., \& Nwabueze, E. (2015). A survey of mosquito larval habitats and species distribution in Rivers State University of Science and Technology Nkpolu PortHarcourt, Nigeria. International Journal of Science and Research, 12, 540-545.

Anosike, J. C., Nwoke, B. E. B., Okere, A. N., Oku, E. E., Asor, J. E., Emmy-Egbe, I. O., \& Adimike, D. A. (2007). Epidemiology of Tree-hole Breeding Mosquitoes in The Tropical Rainforest of Imo State, Southeast Nigeria. Annuals of Agric. and Environ. Medicine, 14, 31-38.

Awolola, T. S., Oyewole, I. O., Koekemoer, L. L., \& Coetzee, M. (2005). Identification of Three Members of Anopheles funestus (Diptera: Culicidae) group and Their Role in Malaria Transmission in two Ecological Zones in Nigeria. Transactions of the Royal Society of Tropical Medicine and Hygiene, 99, 525-531. doi:10.1016/j.trstmh.2004.12.003

Bentley, M. D., \& Day, J. F. (1989). Chemical Ecology and Behavioral Aspects of Mosquito Oviposition. Annual Review of Entomology, 34, 401-421. doi:10.1146/annurev.en.34.010189.002153

Bunza, M. D. A., Suleiman, A. A., Yusuf, A. M., \& Bala, A. Y. (2010). Relative abundance of mosquito species in Katsina metropolis, Katsina state, Nigeria. Nigerian Journal of Parasitology, 2, 73-78.

Egbuche,C.M.,Ezihe,C.K., Aribodor, D.N.,\& Ukonze,C.B.(2016). Survey of mosquitoes in open and closed larval habitats in Aguleri, Anambra East Local Government Area of Anambra State, South eastern Nigeria. Journal of Mosquito Research, 17, 1-5.

Goselle, O. N., Amobi, L. O., Ojile, J. O., David, A., Nanvyat, N., Adulugba, I. A., Kumbak, D., Udeh, E. O., Mbaya, Y. A., \& Mafuyai, H. B. (2017).Abundance of mosquitoes larvae in various microhabitats and the concern for invasion of human community. International Journal of Mosquito Research, 4, 119-125.

Igbinosa, I. B. (1989). Investigations on the breeding site preferences of mosquitoes in Ekpoma, Nigeria. Journal of Applied Entomology, 107, 325-330. doi:10.1111/j.1439-0418.1989.tb00264.x

Jaensen, T. G. T., Niklasson, B., \& Henriksson, B. (1986). Seasonal Activity of Mosquitoes in an Ockelbo Disease Endemic Area in Central Sweden. Journal of American Mosquito Control Association, 2, 18-28.

Mafiana,C.F.(1989). Observation of mosquito species breeding in opening drains and test containers in Lagos Nigeria. Bioscience Research Communication, 1, 95-102.

Mafiana, C. F., Anaeme, L., \& Olatunde, G. O. (1998). Breeding sites of larval Mosquitoes in Abeokuta Nigeria. Nigerian Journal of Entomology, 15, 136-143.

Mbanugo, J. I., \& Okpalaononuju, C. N. (2003). Surveillance of Mosquito Vectors in some Habitats of Awka Metropolis, Anambra, Nigeria. Nigerian Journal of Parasitology, 24, 184-190.

Minakawa, N., Pamela, P., \& Yan, G. (2002). Influence of host and larval habitat distribution on the abundance of African malaria vectors in Western Kenya. American Journal of Tropical Medicine and Hygiene, 67, 32-38. doi:10.4269/ ajtmh.2002.67.32

Oguoma, V. M. \& Ikpeze, O. O. (2008). Species composition and abundance of mosquitoes of a tropical irrigation ecosystem. Animal Research International, 2, 866-871.

Okogun, G. R. A. (2005). Life Table Analysis of Anopheles Malaria Vectors: Generational Mortality as a Tool in Mosquito Vector and Control Studies. Journal of Vector Borne Disease, 42, 43-53.

Okogun, G. R. A., Nwoke, B. E. B., Okere, A. N., Anosike, J. C., \& Esekhegbe, A. C. (2003). Epidemiological implications of preferences of breeding sites of mosquito species in Midwestern Nigeria. Ann. Agric. Envirn. Med, 10, 217-222.

Olayemi, I. K., Omalu, I. C. J., Famotele, O. I., Shegna, S. P., \& Idris, B. (2010). Distribution of mosquito larvae in relation to physic-chemical characteristics of breeding habitats in Minna, north central Nigeria. Review of Infectious Disease, 1, 49-53.

Olayemi, I. K., Ukubuiwe, A. C., \& Oyibo-Usman, K. A. (2014). Mosquito species occurrence and diversity in conventional larval breeding sites in Minna metropolis, Nigeria. International Journal of Innovation and Scientific Research, 1, 86-93. 
Oluwasogo, A. O. ,Adeyemi, M. A.,Gabriel, S.,Kabir, O. O.,Owolabi, A. A., \& Henry, O. S.(2016). Diversity and abundance of Anopheles (Diptera: Culicidae) Species Complex in some selected settlements in Ogbomoso Local Government Area of Oyo State, Nigeria. Malaria Control Elimination, 5, 146. doi:10.4172/2470-6965/1000146

Onyido, A. E., Ezike, V. I., Ozumba, N. A., Nwankwo, A. C. N., \& Nwankwo, E. A. (2009). Yellow fever vectors' surveillance in three satellite communities of Enugu Municipality. The Nigerian Journal of Parasitology, 1, 13-17. doi:10.4314/ njpar.v30i1.43981

Opoku, A. A., Ansa-Asare, O. D. \& Amoako, J. (2005). The Occurrences and Habitat Characteristics of Mosquitoes in Accra, Ghana. CSIR-Water Research Institute.

Sattler, M. A., Mtasiwa, D., Kiama, M., Premji, Z., Tanner, M., Killeen, G. F., \& Lengeler, C. (2005). Habitat characterization and spatial distribution of Anopheles sp. Mosquito larvae in Dares Salaam Tanzania during an extended dry period. Malaria Journal, 4, 4. doi:10.1186/1475-2875-4-4

Service, M. W. (1993).Mosquito Ecology. Field sampling methods. United Kingdom: Elsevier Science Publishers. doi:10.1007/978-94-015-8113-4

Umaru, N. F., Akogun, O. B., \& Owuama C. I. (2006). Species identification ofAnopheles and Culex mosquitoes and its epidemiological implications inYola, Nigeria. Nigerian Journal of Parasitology, 1, 22-31.

Usip, L. P. E., \& Edem, S. I. (2003). Identification of Breeding Sites and Prevalence of Endemic Mosquito Vectors of Parasitic Infection in Uyo Urban, Akwa Ibom State, Nigeria. Acta Zoologica Sinica, 4, 522-524. 